\title{
Influence of the Preliminary Storage on Methane Yield of Anaerobic Digestion of the Organic Fraction of Municipal Solid Waste
}

\author{
Domenica Pangallo ${ }^{1}$, Altea Pedullà ${ }^{1}$, Demetrio Antonio Zema ${ }^{2}$ and Paolo S. Calabrò ${ }^{1, *(D)}$ \\ 1 Department DICEAM, Mediterranean University of Reggio Calabria, Via Graziella, Loc. Feo di Vito, \\ I-89122 Reggio Calabria, Italy; domenica.pangallo.327@studenti.unirc.it (D.P.); \\ pdllta97m66h224v@studenti.unirc.it (A.P.) \\ 2 Department AGRARIA, Mediterranean University of Reggio Calabria, Loc. Feo di Vito, \\ I-89122 Reggio Calabria, Italy; dzema@unirc.it \\ * Correspondence: paolo.calabro@unirc.it; Tel.: +39-0962-1692-222
}

check for updates

Citation: Pangallo, D.; Pedullà, A.; Zema, D.A.; Calabrò, P.S. Influence of the Preliminary Storage on Methane Yield of Anaerobic Digestion of the Organic Fraction of Municipal Solid Waste. Processes 2021, 9, 2017. https://doi.org/10.3390/pr9112017

Academic Editor: Tiancheng Mu

Received: 31 October 2021

Accepted: 9 November 2021

Published: 11 November 2021

Publisher's Note: MDPI stays neutral with regard to jurisdictional claims in published maps and institutional affiliations.

Copyright: (c) 2021 by the authors. Licensee MDPI, Basel, Switzerland. This article is an open access article distributed under the terms and conditions of the Creative Commons Attribution (CC BY) license (https:// creativecommons.org/licenses/by/ $4.0 /)$.

\begin{abstract}
Anaerobic digestion (AD) is a suitable management option for the energy valorization of many wastes, including the organic fraction of municipal solid waste (OFMSW). However, in some cases, long storage after the separate collection of this waste is required for management reasons, especially when the amount of waste to be treated temporarily exceeds the capacity of available AD plants. This study evaluates the biochemical methane potential (BMP) of the OFMSW after preliminary storage of 2, 6, and 10 days, in order to assess whether they are still suitable for AD or not. Moreover, the accuracy of three kinetic models (first order, Gompertz, and logistic models) in estimating the methane yield of stored OFMSW is tested. The resulting methane yield was between about 500 and $650 \mathrm{NmL} \cdot \mathrm{gVs}^{-1}$ and slightly increased with the increase of the storage time after collection. Overall, this study has demonstrated that storage of OFMSW, when the collected amount of solid waste exceeds the treatment capacity of AD plants, a storage time up to 10 days does not impact the methane yield of the process.
\end{abstract}

Keywords: biomethane potential; organic fraction of municipal solid waste; separate collection; storage; volatile solids loss

\section{Introduction}

Anaerobic digestion (AD) is a sustainable and commercially-mature process that allows the conversion of biodegradable waste into biomethane [1]. A wide range of liquid and solid substrates can be fed in the anaerobic digesters, including municipal waste, agricultural and food industry by-products, and animal breeding residues among others [2-4]. The organic fraction of municipal solid waste (OFMSW), also indicated as food waste, is one of the main fractions of municipal solid waste (MSW) [5,6]. OFMSW is a suitable substrate for AD, due to the high biodegradability and biomethane yield [7-9]. However, several strategies have been proposed over the years to optimize AD of OFMSW: pretreatment (e.g., chemical [10], thermal [11], microwave assisted [11]), process set-up (temperature [12], organic loading rate [11], type of digester [13,14]), co-digestion with other substrates [15]. Moreover, the separate collection and treatment of OFMSW prevent its disposal into landfills, and this gives two advantages: energy is produced through $\mathrm{AD}$, and greenhouse gases emissions due to fugitive methane emissions from landfills are avoided [16].

Public institutions at the national level frequently issue regulations, in order to encourage valorization of MSW including OFMSW [17,18]. In many countries, current regulations require that MSW must be separately collected from other waste for its valorization. For instance, in Italy, the minimum level of separate collection set by the national regulation is equal to $65 \%$. To get this high level, the collection of OFMSW is vital, since it usually 
represents the largest MSW fraction [6]. The separately-collected OFMSW is treated by composting, $\mathrm{AD}$, or combined processes (AD followed by composting) [17]. In some local contexts, the capacity of treating plants does not follow the continuous increase in the separate collection. This imbalance determines important management issues with possible environmental and economic constraints.

For example, the Italian regulations [19] consider the OFMSW that is temporarily stored for more than $72 \mathrm{~h}$ after collection as unsuitable for composting plants, in order to avoid odor emissions and other environmental issues. Therefore, in these cases, this MSW fraction must be treated as mixed waste and sent to landfills. The consequences are obviously severe under both the economic and environmental points of view: citizens are not encouraged to increase separate collection and must also support the high cost for the separate collection of OFMSW without any benefits from its valorization. Moreover, the OFMSW stored in landfills releases biogas and leachate, which may pollute air, soil, and groundwater $[16,20,21]$.

The separate collection of OFMSW is usually performed using two main models [5], namely (i) the door-to-door and (ii) the curbside collection; the frequency of both collection systems generally ranges from daily to weekly. As such, the preliminary storage before treatment cannot be avoided. A preliminary deposit time includes in-house storage before collection (i.e., the time between two consecutive drop-offs, which on average is two days according to the usual Italian schedule for waste collection) and storage in municipal depots before treatment.

The preliminary storage process can be considered a form of high-solids microaerobic/anaerobic biologic pretreatment [22]. In fact, during this pre-treatment, enzymatic hydrolysis occurs, due to the presence of hydrolytic anaerobic and facultative bacteria, such as Clostridium, Enterobacterium, and Streptococcus [23]. These microbial strains are able to produce extracellular enzymes that break the cellulose, hemicellulose, and lignin walls in vegetable waste and make proteins, lipids, and other readily biodegradable compounds available (e.g., sugars) [24,25].

The scientific literature on the effects of preliminary storage before the AD of separatelycollected OFMSW is scarce, both because the separate collection of OFMSW is common only in some, mainly European, countries (e.g., Germany and Italy $[6,26])$ and because the storage of this highly biodegradable waste is not a common practice in MSW management. In fact, worldwide, management modes different from those based on separate collection are adopted; often the OFMSW is collected together with mixed waste and destined for incineration $[26,27]$ or landfilling. Another option is the disposal in sewers after mechanical treatment (grinding) [28], however, the benefits of its separate collection and AD treatment have been clearly demonstrated by several authors $[26,28]$.

About the few studies available on the specific topic of this research, Lü et al. [29] stored OFMSW for 0 to 12 days, and then found an increasingly high biochemical methane potential (BMP), as preliminary storage time increased $\left(285-308 \mathrm{NmL} \cdot \mathrm{gVs}_{\mathrm{VS}}{ }^{-1}\right.$ for storage of 2-4 days, and $618-696 \mathrm{NmL} \cdot \mathrm{gVs}^{-1}$ for 5-12 days of storage). Degueurce et al. [30] found that OFMSW stored for a time up to 16 days lost up to $30 \%$ of its initial weight, although its specific methane production increased by about $25 \%$. Feng et al. [31] report that pre-fermentation for 3 days did not influence significantly the BMP of food waste but biomethane production for pre-fermented substrate was faster in the first days. Nilsson Påledal et al. [32] outline a general decreasing trend for BMP with the increase of time but with significant differences if the storage was lower than 10 days and also with respect to environment temperature (e.g., winter and summer conditions) and storage conditions (e.g., in a plastic or paper bag).

The preliminary storage may be an essential step of the management process when the collected amount of OFMSW exceeds the capacity of treatment plants. Therefore, when this waste is destined for $\mathrm{AD}$, the correct evaluation of the BMP after storage is necessary, in order to assess its feasibility. Therefore, this study integrates and consolidates the knowledge about the effects of preliminary storage before the AD of separately-collected 
OFMSW, evaluating the biochemical methane potential (BMP) of the OFMSW after storage of 2, 6, and 10 days, in order to assess whether they are still suitable for AD or not. Moreover, the accuracy of three kinetic models (first order, Gompertz, and logistic models) in estimating the methane yield of the stored OFMSW is assessed. We hypothesize that: (i) the organic matter losses throughout the storage after OFMSW collection may reduce the methane yield of $\mathrm{AD}$, and (ii) some of the three prediction models may give accurate estimations of the cumulated specific methane yields after the storage process.

\section{Materials and Methods}

\subsection{OFMSW Preparation and Characterization}

Synthetic OFMSW samples (700 g) were prepared in the laboratory, following the composition shown in Table 1 and in accordance with a previous study [33].

Table 1. Composition of synthetic OFMSW samples used in this study.

\begin{tabular}{ccc}
\hline Fraction & \% & Weight [g] \\
\hline Vegetable waste (lettuce) & 30 & 210 \\
Fruit waste(fig peels) & 20 & 140 \\
Potato waste & 10 & 70 \\
Meat waste (bovine meat) & 12 & 84 \\
Fish waste (stockfish skin) & 5 & 35 \\
Dairy waste (cheese crust) & 3 & 21 \\
Dry bread & 8 & 56 \\
Cooked rice & 6 & 42 \\
Cooked pasta (spaghetti) & 6 & 42 \\
\hline
\end{tabular}

In order to simulate the conditions of a real waste, each sample was stored at room temperature (about $22{ }^{\circ} \mathrm{C}$ ) for 2, 6, and 10 days in bioplastic bags commonly used for separate collection of OFMSW [34]. To summarize, a total of four samples were prepared:

- $\quad$ Raw sample, (hereafter indicated as $S_{0 \text { days }}$, used as control)

- $\quad$ Sample stored for 2 days $\left(S_{2 \text { days }}\right)$

- $\quad$ Sample stored for 6 days $\left(S_{6 \text { days }}\right)$

- $\quad$ Sample stored for 10 days $\left(\mathrm{S}_{10 \text { days }}\right)$

During storage, the samples were periodically weighed to record the weight loss [35]. After storage, $\mathrm{pH}$, total solids (TS), and volatile solids (VS) were measured on the samples according to the standard methods [36].

\subsection{BMP Tests on Stored OFMSW}

BMP tests were carried out in triplicate for each substrate under mesophilic $\left(35 \pm 0.5^{\circ} \mathrm{C}\right)$ conditions using a self-developed method [37,38]. This method is, however, in compliance with the Italian standard procedure for BMP tests, UNI/TS 11703:2018, and standardized international protocols [39].

The biochemical methane potential (BMP) tests were carried out using glass bottles that were placed in a thermostatic cabinet and mixed with a magnetic stirrer. Each bottle (volume 1.1 L, WTW-Germany) had three necks (two side necks, equipped with septa and the central main neck closed with a stopper) and was loaded with the inoculum, organic substrate, diluting water, and nutrient solutions prepared according to UNI/TS 11703:2018 (Table 2); the volume of each batch was set a $400 \mathrm{NmL}$.

Three times a week, the produced biogas was gently transferred into a second bottle containing an alkaline solution (alkaline trap- $\mathrm{NaOH}$ solution, $3 \mathrm{M}$ ) where $\mathrm{CO}_{2}$ was removed and methane production was evaluated with the water displacement method [40]. 
Table 2. Experimental settings of the batch reactors for the BMP tests.

\begin{tabular}{ccccc}
\hline Substrate & Substrate $\mathbf{( g )}$ & TS $\mathbf{( \% )}$ & S/I & pH \\
\hline $\mathrm{S}_{\text {2days }}$ & 6.0 & 1.8 & 0.3 & $7.23 \pm 0.06$ \\
\hline $\mathrm{S}_{\text {6days }}$ & 4.4 & 1.8 & 0.3 & $7.23 \pm 0.06$ \\
\hline $\mathrm{S}_{10 \text { days }}$ & 5.3 & 1.8 & 0.3 & $7.30 \pm 0.00$ \\
\hline
\end{tabular}

Note: TS = total solids; S/I = substrate to inoculum ratio in terms of Volatile Solids [39,41].

The inoculum was a liquid digestate coming from previous experiments carried out in the same laboratory and stored at $35 \pm 0.5^{\circ} \mathrm{C}$ until the test; inoculum was also characterized before the test.

As required by the UNI/TS 11703:2018 norm, a further BMP test was carried out on inoculum only (blank), in order to measure the non-specific methane production.

Each BMP test lasted 27 days. The daily and cumulated yield of methane was measured. In accordance with the aforementioned norm, the BMP was stopped when the daily production was lower than $1 \%$ of the cumulated volume of methane.

\subsection{Modeling of OFMSW Methane Yield}

The following models were used to estimate the cumulative methane production based on data from the BMP tests: first-order kinetics [42], Gompertz, and logistic. Their analytical expression is reported in Equations (1)-(3), respectively:

$$
\begin{gathered}
B=B_{0} \times[1-\exp (-k \times t)] \\
B=P \times \exp \left\{-\exp \left[\frac{R_{m e}}{P}(\lambda-t)+1\right]\right\} \\
B=\frac{B_{0}}{1+b \times(-k \times t)}
\end{gathered}
$$

where:

- $\quad B_{0}($ or $P)$ and $B\left(\mathrm{NmL} \cdot \mathrm{g}_{\mathrm{vs}}{ }^{-1}\right)$ are the asymptotic and $t$-th day cumulative methane yields, respectively.

- $\quad k\left(\mathrm{~d}^{-1}\right)$ is the kinetic constant.

- $R_{m}\left(\mathrm{NmL} \mathrm{g}_{\mathrm{VS}}{ }^{-1} \cdot \mathrm{d}^{-1}\right)$ is the maximum methane production rate.

- $\lambda(\mathrm{d})$ is the duration of the lag phase.

- $\quad b$ is a numeric constant of the model (3).

- $\quad t(\mathrm{~d})$ is the hydraulic retention time.

$P, R_{m}, \lambda$ in Equation (2), $k$ and $B_{0}$ in Equation (1) and $B_{0}, b$ and $k$ in Equation (3) were determined through the Excel tool "Solver" by minimizing the sum of square errors between the model and the experimental mean values.

\subsection{Final Digestate Analyses}

At the end of the test, the digestate (the residue of $\mathrm{AD}$ ) from each batch was characterized [36], measuring $\mathrm{pH}, \mathrm{TS}, \mathrm{VS}$, the concentration of total volatile fatty acids (VFAs), and the volatile organic acids/buffering capacity (FOS/TAC) ratio [43]. The latter two parameters were determined using a four-point titration method. Before the titration, the digestate sample was prepared by centrifugation at rpm for $10 \mathrm{~min}$. Then, $20 \mathrm{~mL}$ of the liquid phase was poured into a beaker with an immersed $\mathrm{pH}$ electrode and a magnetic stirrer, to ensure a constant mixing of the sample and the added solution $(0.1 \mathrm{~N}$ sulfuric acid 
solution). The amount of solution needed to have a $\mathrm{pH}$ of 5.0,4.4, 4.3, and 4.0, respectively, was measured. This allowed calculating the parameters by Equations (4) and (5) $[43,44]$.

$$
\begin{aligned}
\text { VFAs }\left[m g \cdot L^{-1}\right] & =\left[131340 \times\left(V_{p H_{4.0}}-V_{p H_{5.0}}\right) \times \frac{N_{\mathrm{H}_{2} \mathrm{SO}_{4}}}{V_{\text {sample }}}\right] \\
& -\left[3.08 \times V_{p H_{4.3}} \times \frac{N_{\mathrm{H}_{2} \mathrm{SO}_{4}}}{V_{\text {sample }}} \times 1000\right]-10.9
\end{aligned}
$$

where:

- $\quad V_{p H_{4.0}}=$ Volume in $\mathrm{mL}$ of added solution until $\mathrm{pH}=4.0$

- $\quad V_{p H_{4.3}}=$ Volume in $\mathrm{mL}$ of added solution until $\mathrm{pH}=4.3$

- $\quad V_{p H_{5.0}}=$ Volume in $\mathrm{mL}$ of added solution until $\mathrm{pH}=5.0$

- $\quad V_{\text {sample }}=$ Volume in $\mathrm{mL}$ of sample $(20 \mathrm{~mL})$

- $\quad \mathrm{N}_{\mathrm{H}_{2} \mathrm{SO}_{4}}=$ Normality of acid solution (0.1)

$$
\frac{F O S}{T A C}=\frac{\left[\left(V_{p H_{4.4}} \times 1.66\right)-0.15\right] \times 500}{V_{p H_{5.0}} \times 250}
$$

with FOS expressed as acetic acid equivalent $\left(\mathrm{mgCH}_{3} \mathrm{COOH} \cdot \mathrm{L}^{-1}\right)$ and TAC as calcium carbonate equivalent $\left(\mathrm{mgCaCO} \cdot \mathrm{L}^{-1}\right)$.

\subsection{Statistical Analysis}

A one-way Analysis of Variance (ANOVA) was applied to each of the analyzed parameters ( $\mathrm{pH}, \mathrm{VS}, \mathrm{TS}$, and cumulated specific yield of methane, considered as response variables), assuming time as the variable parameter. The statistical significance of the differences in the response variables was evaluated through pairwise comparisons using Tukey's test (at $p<0.05$ ). To satisfy the equality of variance and normal distribution of sample distribution, the data were processed by normality tests or were square roottransformed whenever necessary. All statistical tests were carried out using XLSTAT rel. 2019.1 software (Addinsoft, Paris, France).

\section{Results}

\subsection{OFMSW Characterization}

During storage, the weight loss of the OFMSW significantly increased from $0.07 \%$ (after two days, sample $S_{2 \text { days }}$ ) to $24.9 \%$ (after 10 days, $S_{10 \text { days }}$ ) (Table 3 ).

Table 3. Characterization of inoculum and substrates used for the BMP tests.

\begin{tabular}{ccccc}
\hline Substrate & Weight Loss [\%] & pH & TS [\%] & VS [\% \\
\hline Inoculum & - & $7.6 \pm 0.05$ & $1.90 \pm 0.03$ & $62.7 \pm 1.48$ \\
$\mathrm{~S}_{\text {0days }}$ & - & $5.9 \pm 0.12 \mathrm{a}$ & $26.7 \pm 0.34 \mathrm{ab}$ & $96.1 \pm 0.14 \mathrm{a}$ \\
$\mathrm{S}_{2 \text { days }}$ & $0.07 \mathrm{a}$ & $5.4 \pm 0.12 \mathrm{~b}$ & $25.0 \pm 1.43 \mathrm{a}$ & $95.5 \pm 0.20 \mathrm{ab}$ \\
$\mathrm{S}_{6 \text { days }}$ & $7.55 \mathrm{~b}$ & $4.9 \pm 0.04 \mathrm{c}$ & $33.9 \pm 0.82 \mathrm{c}$ & $95.1 \pm 1.01 \mathrm{ab}$ \\
$\mathrm{S}_{10 \text { days }}$ & $24.9 \mathrm{c}$ & $5.4 \pm 0.03 \mathrm{~b}$ & $28.3 \pm 0.97 \mathrm{~b}$ & $94.7 \pm 0.17 \mathrm{~b}$ \\
\hline Notes: TS = total solids; VS $=$ volatile solids; different letters indicate significant differences at $p<0.05$.
\end{tabular}

The $\mathrm{pH}$ slightly decreased (from $5.9 \pm 0.12, \mathrm{~S}_{0 \text { days }}$, to $4.9 \pm 0.04, \mathrm{~S}_{6 \text { days }}$ ) in the first days and then stabilized. Moreover, the VS content slightly decreased over time, from $96.1 \pm 0.14 \%, \mathrm{~S}_{0 \text { days }}$, to $94.7 \pm 0.17 \%, \mathrm{~S}_{10 \text { days. }}$. The difference was significant only between the samples collected without any storage and after 10 days. In contrast, the decrease in TS over time was not monotonic, since the highest VS content was measured after two days of storage (sample $\mathrm{S}_{2 \text { days }}, 25.0 \pm 1.43 \%$ ) and the highest content after six days $\left(\mathrm{S}_{6 \text { days }}\right.$, $33.9 \pm 0.82 \%)$. Only the latter content of VS was significantly different from the other samples (Table 3). 


\subsection{Biogas and Methane Yield of OFMSW}

The maximum biogas and methane yields of the stored OFMSW was measured for the sample stored for six days ( $874 \pm 5.8 \mathrm{NmL} \cdot \mathrm{gVS}^{-1}$ and $644 \pm 7.8 \mathrm{NmL} \cdot \mathrm{gVS}^{-1}$, respectively) compared to the values measured after two days $\left(683 \pm 18.3\right.$ and $\left.495 \pm 14.0 \mathrm{NmL} \cdot \mathrm{g}_{\mathrm{VS}}{ }^{-1}\right)$. The methane yield of the sample stored for 10 days slightly decreased (compared to the value of the sample $\mathrm{S}_{6 \mathrm{days}}$ ) to $804 \pm 45.4$ and $594 \pm 34.3 \mathrm{NmL} \cdot \mathrm{g}_{\mathrm{VS}}{ }^{-1}$, respectively; this decrease was also significant compared to the other samples. The mean methane content was between $48.0 \pm 7.0 \%\left(\mathrm{~S}_{2 \text { days }}\right)$ and $53.0 \pm 7.07\left(\mathrm{~S}_{10 \text { days }}\right)($ Table 4$)$.

Table 4. Biogas and methane yields of the BMP tests.

\begin{tabular}{|c|c|c|c|c|}
\hline Substrate & Sample & $\begin{array}{l}\text { Biogas Yield } \\
\left(\mathrm{NmL} \cdot \mathrm{g}_{\mathrm{VS}}{ }^{-1}\right)\end{array}$ & $\begin{array}{l}\text { Methane Yield } \\
\left(\mathrm{NmL} \cdot \mathrm{g}_{\mathrm{VS}}{ }^{-1}\right)\end{array}$ & $\begin{array}{c}\text { Methane Content } \\
(\%)\end{array}$ \\
\hline $\mathrm{S}_{2 \text { days }}$ & $\begin{array}{l}1 \\
2 \\
3\end{array}$ & $683 \pm 18.3 a$ & $495 \pm 14.0 \mathrm{a}$ & $48.0 \pm 7.0 \mathrm{a}$ \\
\hline$S_{6 \text { days }}$ & $\begin{array}{l}4 \\
5 \\
6\end{array}$ & $874 \pm 5.8 b$ & $644 \pm 7.8 b$ & $52.0 \pm 3.5 b$ \\
\hline $\mathrm{S}_{10 \text { days }}$ & $\begin{array}{l}7 \\
8 \\
9\end{array}$ & $804 \pm 45.4 b$ & $594 \pm 34.3 b$ & $53.0 \pm 7.1 \mathrm{~b}$ \\
\hline
\end{tabular}

Notes: VS = volatile solids; different letters indicate significant differences at $p<0.05$.

\subsection{Estimation of OFMSW Methane Yield by Prediction Models}

Figure 1 depicts the cumulated methane production of OFMSW for the three samples and the fitting by the three prediction models, while Table 5 reports the model parameters.

Table 5. Parameters of the prediction models to estimate the OFMSW methane yield.

\begin{tabular}{|c|c|c|c|c|c|c|c|c|c|c|c|}
\hline \multirow{3}{*}{ Substrate } & \multicolumn{11}{|c|}{ Prediction Model } \\
\hline & \multicolumn{3}{|c|}{ First Order } & \multicolumn{4}{|c|}{ Gompertz } & \multicolumn{4}{|c|}{ Logistic } \\
\hline & $\begin{array}{c}B_{0} \\
\left(\mathrm{NmL} \cdot \mathrm{g}_{\mathrm{Vs}}{ }^{-1}\right)\end{array}$ & $\begin{array}{c}k \\
\left(d^{-1}\right)\end{array}$ & $R^{2}$ & $\begin{array}{c}P \\
\left(\mathrm{NmL} \cdot \mathrm{g}_{\mathrm{VS}}{ }^{-1}\right)\end{array}$ & $\begin{array}{c}\lambda \\
(d)\end{array}$ & $\begin{array}{c}R_{m} \\
\left(\mathrm{NmL} \cdot \mathrm{g}_{\mathrm{VS}}{ }^{-1} \cdot \mathrm{d}^{-1}\right)\end{array}$ & $R^{2}$ & $\begin{array}{c}B_{0} \\
\left(\mathrm{NmL} \cdot \mathrm{g}_{\mathrm{Vs}}{ }^{-1}\right)\end{array}$ & $\begin{array}{c}k \\
\left(d^{-1}\right)\end{array}$ & $B$ & $R^{2}$ \\
\hline$S_{2 \text { days }}$ & 0.501 & 0.191 & 0.991 & 0.488 & 0.000 & 0.060 & 0.998 & 0.489 & 0.363 & 4.272 & 0.999 \\
\hline $\mathrm{S}_{6 \text { days }}$ & 0.638 & 0.223 & 0.999 & 0.625 & 0.000 & 0.090 & 0.998 & 0.621 & 0.514 & 6.330 & 0.997 \\
\hline $\mathrm{S}_{10 \text { days }}$ & 0.636 & 0.129 & 0.997 & 0.597 & 0.574 & 0.060 & 0.996 & 0.587 & 0.404 & 10.164 & 0.998 \\
\hline
\end{tabular}

The logistic model was the most reliable to estimate the methane yield after 2 and 10 days of storage with a coefficient of determination $\left(R^{2}\right)$ of nearly 1 and over 0.98 , respectively, while the first-order model was less accurate compared to the other tested models, since did $\mathrm{R}^{2}$ not exceed 0.991 . The modified Gompertz model also fitted very well the experimental measures, as shown by a minimum $R^{2}$ of 0.996 (Table 5).

The first-order kinetic model gave $k$ values ranging from 0.129 ( $\left.\mathrm{S}_{10 \text { days }}\right)$ to 0.223 $\left(\mathrm{S}_{6 \text { days }}\right)$. The modified Gompertz model did not show any lag phase for all the samples except that for sample. $S_{10 \text { days }} R_{m}$, the kinetic term in the Gompertz model, was the same $\left(0.06\left(\mathrm{NmL} \mathrm{gVs}^{-1} \cdot \mathrm{d}^{-1}\right)\right)$ for the samples $\mathrm{S}_{2 \text { days }}$ and $\mathrm{S}_{10 \text { days }}$ while it was higher by $50 \%$ for the sample $\mathrm{S}_{6 \text { days }}$. This trend is confirmed for the kinetic term $(k)$ in the Logistic model with similar values for samples $S_{2 \text { days }}$ and $S_{10 \text { days }}$ and a higher value for $S_{6 \text { days }}$. 

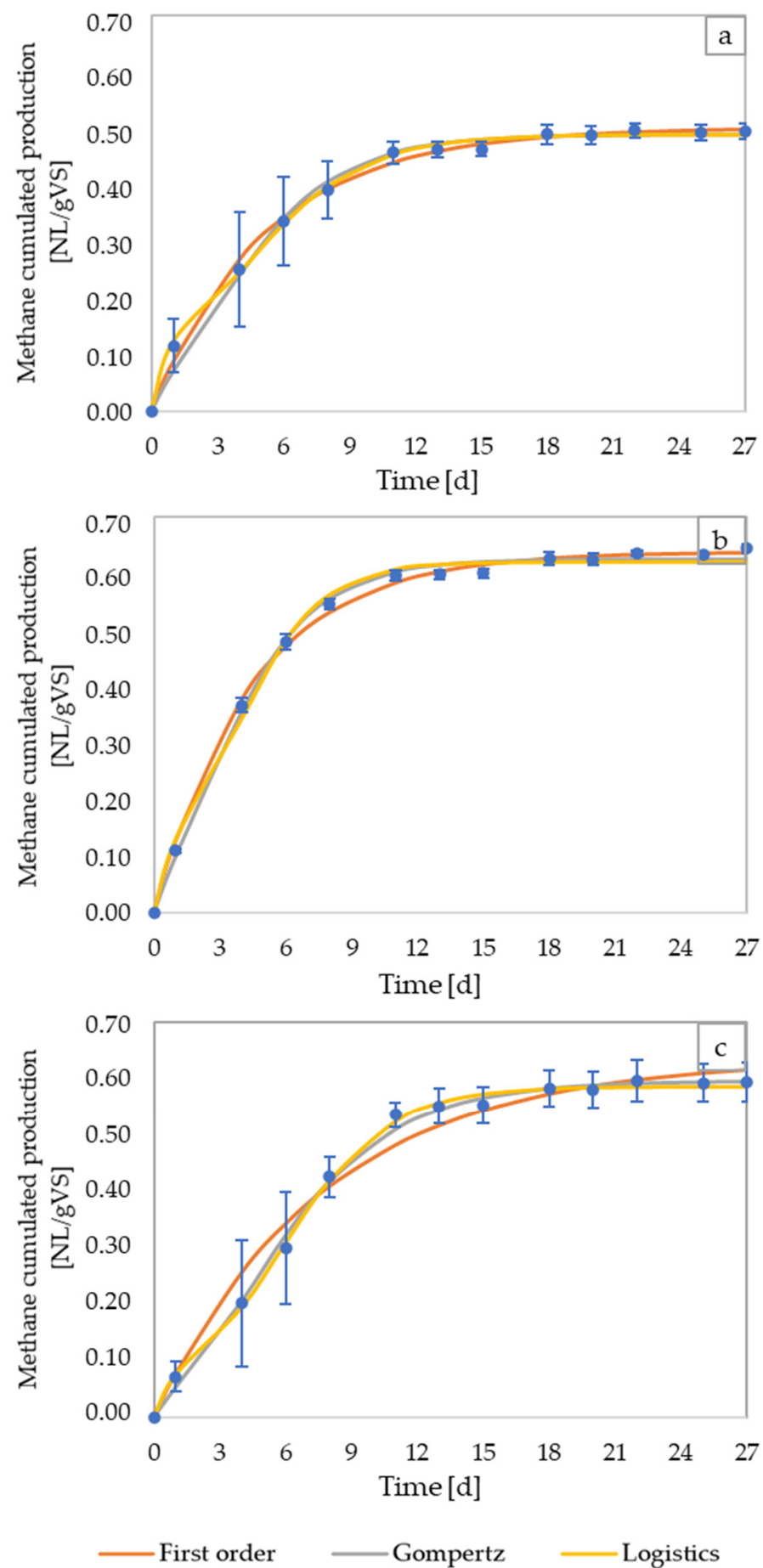

- Specific cumulative net methane average production

Figure 1. Specific cumulated production of methane measured in the BMP tests and modeled by three prediction models after $2(\mathbf{a}), 6$ (b), and 10 (c) days of OFMSW storage.

\section{Discussion}

The BMP tests after storage with different durations have allowed the evaluation of the possible energy losses during the process. Storage determined weight loss of the OFMSW, which significantly increased over time, and this increase was presumably due to water evaporation thanks to the consistency of the biodegradable bag [35].

The slight increase in $\mathrm{pH}$ and decrease in VS content during storage were expected since the acids of OFMSW were degrading and OM degraded. The non-monotonic decrease 
in TS over time was not monotonic, since the highest VS content measured after two six days should presumably be an outlier, due to an imperfect composition of the sample for substrate heterogeneity. It is worth noting that the aforementioned difference in TS of the sample $S_{6 \text { days }}$ might not affect the measured BMP since the latter is referred to a specific amount ( $1 \mathrm{~g})$ of VS.

The sample stored for six days gave the maximum energy yield of the stored OFMSW, while the methane potential was lower for the other storage times, especially for a storage process lasting two days. Presumably, throughout the early days of storage, hydrolysis facilitated the subsequent digestion process, while, if the storage was prolonged, a higher share of organic matter would have been lost. These results are basically in agreement with other studies $[29,30]$, where the maximum BMP was recorded after storage of 5-7 days.

To fully appreciate the effect of the storage, the evaluation of the VS loss over time by a simple mass balance is needed. After two days, the substrate had lost $11.6 \%$ of the initial VS content. After six days, an increase of $5.9 \%$ was recorded; the loss increased to $23.1 \%$ after 10 days. The lower loss recorded after six days may be another proof of the different sample compositions. For these reasons, the specific methane production referred to as the initial VS content was not calculated for this sample.

A survey on 102 samples collected worldwide [45] reported an average value of $460 \mathrm{NmL} \cdot \mathrm{gVS}^{-1}$ that is very close to the measure of this research for $S_{2 \text { days }}$ sample. When the yield was referred to the initial VS content rather than to the current value (that is, to the VS content on the second or tenth day of the test) the specific methane production was $436 \pm 15.1$ (sample $S_{2 \text { days }}$ ) and $457 \pm 32.3\left(S_{10 \text { days }}\right) \mathrm{NmL} \mathrm{gVS}^{-1}$, respectively. This confirms that even if the VS loss is accounted for the BMP remains very close to the worldwide average [45].

These values confirm that storage does not reduce the methane yield of the AD of the OFMSW separately collected.

Regarding the methane yield prediction, all the three tested models showed high reliability, shown by the exceptionally high coefficients of determination. The logistic model generally was the most accurate, while the first-order model showed the less satisfactory prediction capacity for the shortest storage duration (two days).

In addition to the ultimate production, presumably thanks to efficient hydrolysis during storage, methane production is faster for the sample $S_{6 \text { days }}$, this result is basically in agreement with that reported by Feng et al. [31]. The prediction of the ultimate methane production is similar for all the models.

This paper demonstrates that this topic is worthy of further research. Future steps are the use of larger samples (about $15 \mathrm{~L}$ ) of real waste randomly sampled over the different seasons of the year to evaluate the impact of both the variation of OFMSW composition and of environment temperature. Another planned improvement is the use of larger reactors (2-4 L) for BMP measurement.

\section{Conclusions}

The BMP tests performed at lab scale on household organic waste stored for a period of 2, 6, and 10 days regularly evolved, yielding a slightly higher methane production (between 600 and $650 \mathrm{NmL}_{\mathrm{CH} 4} \cdot \mathrm{g}_{\mathrm{VS}}{ }^{-1}$ ) compared to the mean values of the global literature. Moreover, the study has indicated that storage after collection does not reduce the methane yield of the anaerobic process, in spite of the expected organic matter losses. The three prediction models tested used the laboratory data gave accurate estimations of the cumulated specific methane yields, also if the logistic model seemed slightly more reliable and accurate compared to the Gompertz and first-order ones.

Overall, this study has indicated that storage of OFMSW up to 10 days does not impact the methane yield of the process when the collected amount of solid waste exceeds the treatment capacity of AD plants; however, the practical problems concerning the management of the storage related to the production of leachate and to odors emissions must be taken into account. 
Author Contributions: Conceptualization, P.S.C.; Formal analysis, D.P., A.P. and D.A.Z.; Investigation, D.P. and A.P.; Methodology, P.S.C.; Resources, P.S.C.; Supervision, P.S.C.; Validation, D.A.Z.; Visualization, D.P. and A.P.; Writing-original draft, D.P., A.P., D.A.Z. and P.S.C.; Writingreview and editing, D.A.Z. and P.S.C. All authors have read and agreed to the published version of the manuscript.

Funding: This research received no external funding.

Data Availability Statement: Raw data can be requested from the corresponding author.

Acknowledgments: The authors sincerely thank Mariastella Ferreri for her help during the laboratory activity. This work is dedicated to R. Pietropaolo, in honor of his 80th birthday.

Conflicts of Interest: The authors declare no conflict of interest.

\section{References}

1. Thamsiriroj, T.; Nizami, A.S.; Murphy, J.D. Use of modeling to aid design of a two-phase grass digestion system. Bioresour. Technol. 2012, 110, 379-389. [CrossRef] [PubMed]

2. Ward, A.J.; Hobbs, P.J.; Holliman, P.J.; Jones, D.L. Optimisation of the anaerobic digestion of agricultural resources. Bioresour. Technol. 2008, 99, 7928-7940. [CrossRef] [PubMed]

3. Zema, D.; Calabrò, P.; Folino, A.; Tamburino, V.; Zappia, G.; Zimbone, S. Valorisation of citrus processing waste: A review. Waste Manag. 2018, 80, 252-273. [CrossRef] [PubMed]

4. Calabrò, P.S.; Folino, A.; Tamburino, V.; Zappia, G.; Zema, D.A. Increasing the tolerance to polyphenols of the anaerobic digestion of olive wastewater through microbial adaptation. Biosyst. Eng. 2018, 172, 19-28. [CrossRef]

5. Calabrò, P.; Satira, A. Recent advancements toward resilient and sustainable municipal solid waste collection systems. Curr. Opin. Green Sustain. Chem. 2020, 26, 100375. [CrossRef]

6. Calabrò, P.S.; Pangallo, D. Analysis of the Effect of Separate Collection on the Composition of Mixed Municipal Solid Waste in Italy. Open Chem. Eng. J. 2020, 14, 63-70. [CrossRef]

7. Zamri, M.; Hasmady, S.; Akhiar, A.; Ideris, F.; Shamsuddin, A.; Mofijur, M.; Fattah, I.M.R.; Mahlia, T. A comprehensive review on anaerobic digestion of organic fraction of municipal solid waste. Renew. Sustain. Energy Rev. 2020, 137, 110637. [CrossRef]

8. Mata-Alvarez, J.; Dosta, J.; Romero-Güiza, M.; Fonoll, X.; Peces, M.; Astals, S. A critical review on anaerobic co-digestion achievements between 2010 and 2013. Renew. Sustain. Energy Rev. 2014, 36, 412-427. [CrossRef]

9. Hartmann, H.; Ahring, B.K. Strategies for the anaerobic digestion of the organic fraction of municipal solid waste: An overview. Water Sci. Technol. 2006, 53, 7-22. [CrossRef]

10. Siciliano, A.; Limonti, C.; Curcio, G.M. Improvement of Biomethane Production from Organic Fraction of Municipal Solid Waste (OFMSW) through Alkaline Hydrogen Peroxide (AHP) Pretreatment. Fermentation 2021, 7, 197. [CrossRef]

11. Kazimierowicz, J.; Zieliński, M.; Dębowski, M. Influence of the Heating Method on the Efficiency of Biomethane Production from Expired Food Products. Fermentation 2021, 7, 12. [CrossRef]

12. Gao, Y.; Kong, X.; Xing, T.; Sun, Y.; Zhang, Y.; Luo, X.; Sun, Y. Digestion Performance and Microbial Metabolic Mechanism in Thermophilic and Mesophilic Anaerobic Digesters Exposed to Elevated Loadings of Organic Fraction of Municipal Solid Waste. Energies 2018, 11, 952. [CrossRef]

13. Lavagnolo, M.C.; Girotto, F.; Rafieenia, R.; Danieli, L.; Alibardi, L. Two-stage anaerobic digestion of the organic fraction of municipal solid waste-Effects of process conditions during batch tests. Renew. Energy 2018, 126, 14-20. [CrossRef]

14. Le Pera, A.; Sellaro, M.; Migliori, M.; Bianco, M.; Zanardi, G. Dry Mesophilic Anaerobic Digestion of Separately Collected Organic Fraction of Municipal Solid Waste: Two-Year Experience in an Industrial-Scale Plant. Processes 2021, 9, 213. [CrossRef]

15. Kazimierowicz, J.; Dzienis, L.; Dębowski, M.; Zieliński, M. Optimisation of methane fermentation as a valorisation method for food waste products. Biomass. Bioenergy 2020, 144, 105913. [CrossRef]

16. Calabrò, P.S.; Gori, M.; Lubello, C. European trends in greenhouse gases emissions from integrated solid waste management. Environ. Technol. 2015, 36, 2125-2137. [CrossRef]

17. ISPRA. Rapporto Rifiuti Urbani-Edizione 2020; ISPRA: Rome, Italy, 2020.

18. EEA. Bio-Waste in Europe-Turning Challenges into Opportunities-European Environment Agency; Publications Office of the European Union: Luxembourg, 2020; ISBN 978-92-9480-223.

19. Ministero Dell'ambiente e Della Tutela del Territorio e del Mare Decreto 8 April 2008. On the Centers for the Separate Collection of Municipal Solid Waste; Serie Generale, n. 99; Ministero Dell'ambiente e Della Tutela Del Territorio e Del Mare: Roma, Italy, 2008; (In Italian)

20. Calabrò, P.S.; Orsi, S.; Gentili, E.; Carlo, M. Modelling of biogas extraction at an Italian landfill accepting mechanically and biologically treated municipal solid waste. Waste Manag. Res. 2011, 29, 1277-1285. [CrossRef]

21. Sindhu, R.; Gnansounou, E.; Rebello, S.; Binod, P.; Varjani, S.; Thakur, I.S.; Nair, R.B.; Pandey, A. Conversion of food and kitchen waste to value-added products. J. Environ. Manag. 2019, 241, 619-630. [CrossRef] 
22. Rafieenia, R.; Girotto, F.; Peng, W.; Cossu, R.; Pivato, A.; Raga, R.; Lavagnolo, M.C. Effect of aerobic pre-treatment on hydrogen and methane production in a two-stage anaerobic digestion process using food waste with different compositions. Waste Manag. 2017, 59, 194-199. [CrossRef]

23. Cheng, F.; Brewer, C. Conversion of protein-rich lignocellulosic wastes to bio-energy: Review and recommendations for hydrolysis + fermentation and anaerobic digestion. Renew. Sustain. Energy Rev. 2021, 146, 111167. [CrossRef]

24. Carrere, H.; Antonopoulou, G.; Affes, R.; Passos, F.; Battimelli, A.; Lyberatos, G.; Ferrer, I. Review of feedstock pretreatment strategies for improved anaerobic digestion: From lab-scale research to full-scale application. Bioresour. Technol. 2016, 199, 386-397. [CrossRef] [PubMed]

25. Antonopoulou, G.; Dimitrellos, G.; Vayenas, D.; Lyberatos, G. Different Physicochemical Pretreatment Methods on Lignocellulosic Biomass: The Efeect on Biochemical Methane Potential. In Proceedings of the 14th International Conference on Environmental Science and Technology, Rhodes, Greece, 3-5 September 2015.

26. Mayer, F.; Bhandari, R.; Gäth, S.A.; Himanshu, H.; Stobernack, N. Economic and environmental life cycle assessment of organic waste treatment by means of incineration and biogasification. Is source segregation of biowaste justified in Germany? Sci. Total Environ. 2020, 721, 137731. [CrossRef] [PubMed]

27. Jensen, M.B.; Møller, J.; Scheutz, C. Comparison of the organic waste management systems in the Danish-German border region using life cycle assessment (LCA). Waste Manag. 2016, 49, 491-504. [CrossRef]

28. Thomsen, M.; Romeo, D.; Caro, D.; Seghetta, M.; Cong, R.-G. Environmental-Economic Analysis of Integrated Organic Waste and Wastewater Management Systems: A Case Study from Aarhus City (Denmark). Sustainability 2018, 10, 3742. [CrossRef]

29. Lü, F.; Xu, X.; Shao, L.; He, P. Importance of storage time in mesophilic anaerobic digestion of food waste. J. Environ. Sci. 2016, 45, 76-83. [CrossRef]

30. Degueurce, A.; Picard, S.; Peu, P.; Tremier, A. Storage of Food Waste: Variations of Physical-Chemical Characteristics and Consequences on Biomethane Potential. Waste Biomass. Valorization 2019, 11, 2441-2454. [CrossRef]

31. Feng, K.; Li, H.; Deng, Z.; Wang, Q.; Zhang, Y.; Zheng, C. Effect of pre-fermentation types on the potential of methane production and energy recovery from food waste. Renew. Energy 2019, 146, 1588-1595. [CrossRef]

32. Påledal, S.N.; Hellman, E.; Moestedt, J. The effect of temperature, storage time and collection method on biomethane potential of source separated household food waste. Waste Manag. 2018, 71, 636-643. [CrossRef]

33. Calabrò, P.S.; Fazzino, F.; Pangallo, D. How does separate collection efficiency influence biological stability of commingled Italian municipal solid waste? Sustain. Chem. Pharm. 2020, 19, 100355. [CrossRef]

34. Calabro', P.; Folino, A.; Fazzino, F.; Komilis, D. Preliminary evaluation of the anaerobic biodegradability of three biobased materials used for the production of disposable plastics. J. Hazard. Mater. 2019, 390, 121653. [CrossRef]

35. Dolci, G.; Catenacci, A.; Malpei, F.; Grosso, M. Effect of Paper vs. Bioplastic Bags on Food Waste Collection and Processing. Waste Biomass. Valorization 2021, 12, 6293-6307. [CrossRef]

36. APHA. Standard Method for Examination of Water and Wastewater, 22nd ed.; American Public Health Association: Washington, DC, USA, 2012; ISBN 9780875530130.

37. Calabrò, P.; Paone, E.; Komilis, D. Strategies for the sustainable management of orange peel waste through anaerobic digestion. J. Environ. Manag. 2018, 212, 462-468. [CrossRef] [PubMed]

38. Calabrò, P.; Panzera, M. Biomethane production tests on ensiled orange peel waste. Int. J. Heat Technol. 2017, 35, S130-S136. [CrossRef]

39. Holliger, C.; Alves, M.; Andrade, D.; Angelidaki, I.; Astals, S.; Baier, U.; Bougrier, C.; Buffière, P.; Carballa, M.; De Wilde, V.; et al. Towards a standardization of biomethane potential tests. Water Sci. Technol. 2016, 74, 2515-2522. [CrossRef]

40. Schievano, A.; Scaglia, B.; D’Imporzano, G.; Malagutti, L.; Gozzi, A.; Adani, F. Prediction of biogas potentials using quick laboratory analyses: Upgrading previous models for application to heterogeneous organic matrices. Bioresour. Technol. 2009, 100, 5777-5782. [CrossRef]

41. Raposo, F.; Banks, C.; Siegert, I.; Heaven, S.; Borja, R. Influence of inoculum to substrate ratio on the biochemical methane potential of maize in batch tests. Process. Biochem. 2006, 41, 1444-1450. [CrossRef]

42. Donoso-Bravo, A.; Pérez-Elvira, S.I.; Fdz-Polanco, F. Application of simplified models for anaerobic biodegradability tests. Evaluation of pre-treatment processes. Chem. Eng. J. 2010, 160, 607-614. [CrossRef]

43. Liebetrau, J.; Pfeiffer, D.; Thrän, D. Collection of Methods for Biogas; DBFZ Deutsches Biomasseforschungszentrum Gemeinnützige GmbH: Leipzig, Germany, 2016.

44. Mézes, L.; Tamas, J.; Borbely, J. Novel approach of the basis of FOS/TAC method. An. Univ. Ii Din Oradea Fasc. Protecţia Mediu. 2011, 17, 713-718.

45. Fisgativa, H.; Tremier, A.; Dabert, P. Characterizing the variability of food waste quality: A need for efficient valorisation through anaerobic digestion. Waste Manag. 2016, 50, 264-274. [CrossRef] 